\title{
Analysis of Connotation of Readers' Right
}

\author{
Ruiying Wang \\ Dezhou University \\ Dezhou 253023, Shandong, China \\ E-mail: cxwry@sina.com
}

This paper is one of the research results of "Construction of High School Library and Local Cultural Service System" in the social scientific planned project in Dezhou. (Project No: 08YD007)

\begin{abstract}
The paper illustrates the production of readers' right, its characteristics, legal basis, and analyzes its connotation from the perspective of seven aspects, including right of education, right of reading, right of information acquisition, right of privacy secrecy, Right of cultural and scientific progress and right of social culture and living, etc.

Keywords: Readers' right, Right of education, Right of reading, Right of information acquisition, Right of privacy secrecy, Right of cultural and scientific progress

As a cultural right and educational right, readers' right is endowed with confirmation and guarantee in a legal form by the country. The Article 41, Article 42 and Article 50 of The Education Law of the People's Republic of China stipulate that, "The nation encourages schools and other educational institutions and social organizations to take measures to create conditions for permanent education for its citizens"; "educatees enjoy the rights to "use educational teaching facilities, equipment and books and reference materials"; "libraries, museums, science museums and cultural centers, etc, provide convenience for educatees to accept education”. That is to say, readers' right is one type of cultural rights, and each citizen should have the right to enjoy it, just as they have the political right, economic right and social right.
\end{abstract}

\section{Concept, production and characteristics of readers' right}

To present it simply, readers' right refers to the right of readers to utilize book resources in a library to acquire knowledge and information. Specifically speaking, it means that a country offers book resources and a user acquires knowledge and information by means of borrowing the resources or reading them with freedom. The essence of readers' right is the right of freedom of information on the part of citizens, and it is the final target to be realized for a library information institution to be set up and run. The target of all sorts of legal relations between readers and a library, including relations of employing document information resources in the library, its facilities and equipment, and of receiving services and management of the library, is to utilize freely all sorts of resources in the library and to acquire advanced cultural, scientific and technical information.

Readers' right was born with emergence of modern libraries. At the time of ancient libraries, books and literature were unique to upper classes of the society, and were symbol of their political status and social identity. In 1850, with efforts of Edwards. E. (1812-1886), the British Parliament passed the first law about Public Library. Issuance of this law brought a new institution/system for hundreds of millions of people to permanently share informational justice and information democracy, namely, public library. Thereout, library switched from upper social classes of noblemen and imperial power to poor people. It was only from then that common citizens had readers' qualifications and the right to utilize a library---readers' right.

It was not until a discussion in 1980s that readers began to pay attention to readers' right. At that time, Japan adopted the means of entrusted management in order to reduce cost of public library, and employed librarians of non-library profession, as a result of which service quality was reduced and readers' right was not realized and even was violated. Right of a library aroused attention of researchers, and the Scholar Susumu Sasaki wrote Right Manifesto of Library Users. Library users referred to readers. From the perspective of law, readers' right has the following characteristics: firstly, readers' right belongs to cultural right. Similar to political right, economic right and social right of citizens, their cultural right is also a fundamental right they should share, and their right to utilize a library is a sort of their cultural 
right. Secondly, readers' right belongs to the right of education. Thirdly, readers only share the right to utilize resources in a library, but don't have the right to possess them. Document resources belong to the state or collectives, and readers' only have the right to utilize them. Fourthly, readers' right coincides with readers' obligation. There is no right without any obligation, and likewise, there is no obligation without any right. Any right is related with an obligation. At the time of adequately sharing resources in a library, readers also have the obligation to abide by rules and regulations in a library, to protect integrity of library resources with self-consciousness and protect them from being violated.

On December 16, 1966, the United Nations passed International Covenant on Economic, Social and Cultural Rights, in which the Article 15 made stipulations on cultural right as follows, "1). All treaty members of this convenant admitted that each one had the following rights: a). to participate in cultural life; b). to share scientific progress and any benefit generated by its application; c). any spiritual and material interest generated in science, arts and works of art should be protected. 2). Procedures adopted by all treaty members of the convenant to adequately realize this right should include procedures necessary to preserve, develop and disseminate science and culture. 3 ). All treaty members of the convenant assume and respect the indispensable freedom necessary for any scientific research and creation activities." The convenant came into effect from January 3, 1975. Chinese government sighed this convenant on October 27, 1997, and the Ninth Standing Committee of the National People's Congress passed it on February 28, 2001. It finally came into effect from July 2001. However, which rights can readers exercise in a library?

\section{Rights shared by readers}

\subsection{Readers' right of education}

Library emerged with demand on education, and its educational function will accompany the career of library all through its life. Ramesses II (BC 1304-BC 1237), the $19^{\text {th }}$ Dynasty of Ancient Egypt, established a library with its access point carved with the typeface of "saving the soul". However, emergence of modern public libraries was due to improvement of workers' culture and technology brought about by development of the capitalist economy in Britain in the middle of the $19^{\text {th }}$ Century. At that time, some library scholars advocated and managed a public library as an educational institution to popularize cultural knowledge. Public Library Manifesto had the following definite stipulations on educational functions of public library, "Public library is a channel for human beings to seek for knowledge and it provides fundamental conditions for permanent education, free decision making and cultural development of an individual and a social group", and "regular education at all levels is supported and individual and self-learning education is also supported."

Library education has the following features: 1). Universality. Library is an institutional arrangement of information equality under conditions of democratic politics, and each social member has the right to share document information in a public library and to educate by oneself. It is stipulated in Public Library Manifesto that, "Each one has the right to equally share service in a public library, without constraints of age, race, gender, religion or social status.” 2). Constancy. A public library has the functions to preserve document, inherit civilization and protect traditions, so its document resources have the characteristics of comprehensiveness and constancy, which determines its educations means is distinguished from characteristics of school education, adult education and training education. Public library can assume the capacity of citizens to share permanent education.

\subsection{Readers' right of reading}

Reading is the primary approach to acquisition of knowledge and to development of production capability since the civilization of human kind. The Library Charter by the UNESCO in 1972 stipulated that, "Each one has the right of reading. The society is obliged to guarantee that each one has the opportunity to read." In the era of knowledge-driven economy, the significance of reading to develop cultural production capability seems especially obvious, because the key element of cultural production capability includes people's intelligence, the scientific production and management, labor organization and cultural resources, etc. Cultural production capability is characterized by "culture".

As a primary reading occasion, library plays a dominant role in realizing readers' right of reading. For guarantee of citizens' right of reading, a library should provide fundamental facilities, document resources and service, and especially public libraries in former revolutionary base areas, areas inhabited by minority nationalities, remote and border areas and poverty-stricken areas should ensure to satisfy people's reading requirements and necessity of spiritual and cultural life. However, the actual situation allows of no optimist. According to statistics by the Ministry of Culture in 2000, there were altogether 144 counties without any library, and there were 108 county libraries without residence. The extensive rural areas even didn't have libraries with organizational structure. In 2003, there were altogether 124 county libraries without shelves or collected books. In the $17^{\text {th }}$ Session of the General Assembly, Hu Jintao put forward, "We should develop non-profit cultural undertakings as a primary approach to guarantee basic cultural interest of people, strengthen investment and intensify community and rural cultural facility construction", which was extremely timely and was also quite necessary. A library should resort to the driving force of the $17^{\text {th }}$ Session of the General Assembly to quicken its step and to establish gradually self-contained library public cultural service system, so as to guarantee realization of people's right of reading. 


\subsection{Readers' right of information acquisition}

Right of information is the basic right a citizen should share. Right of information refers to the right of a citizen to undertake information activities with freedom pursuant to the law, including free acquisition, production and dissemination of information. Unlimited openness of information is one of the conditions for people to participate in social construction and democratic development. Public library is the tool/institutional arrangement to guarantee free and fair acquisition on the part of citizens under the democratic political condition. Since its birth in the middle of 1800s, public library has always been assuming this task. With development of network technology and digital technology, the society has been disintegrated into two hierarchies, that is, information-rich and information-poor. As the tool of information equality, public library behoves and should guarantee the right of citizens to acquire information with freedom. Library should provide citizens with retrieval and utilization of Internet/World Wide Web free of charge, so that each one can use information via the electronic carrier regardless of their economic conditions.

\subsection{Readers' right of privacy secrecy}

In 1979, in the Library Freedom Manifesto revised by Japan stipulated definitely, “A library should keep secrets for its users". A library may master the following information of readers going to the library and not going to the library: (1). Personal information, including the real name of readers, address, affiliation, occupation, gender, telephone, ID number, E-mail and electronic signature, etc. (2). Academic information, including readers' reading interest, reading trend and reading content, etc, which is necessary for a scholar. Then, he/she can analyze their research fields, research direction and even research subjects. (3). Internet meandering information. Website visited by readers or information they have browsed can either be stored in the server of the library in the form of a log file, or can be stored in the computer used by the readers in the form of Cookie. As for all sorts of information of readers, a librarian shouldn't search, store, disseminate, employ or sell whether it is acquired actively or passively.

For protection of readers' right of privacy secrecy, western countries have gone before us, such as, Family Education and Privacy Act and Privacy Act by America in 1970s and 1980s, and General Principles about Personal Privacy Secrecy on the Internet by EU, etc, whereas China is still not sound in terms of laws in this aspect.

\subsection{Readers' right of cultural and scientific progress}

The feature of public library to collect document information and inherit civilization and the characteristics of freedom, equality and service free of charge not only enables each sort of document to have its own readers, but can enable each reader to find out the necessary document information. Anyone can acquire service of a library at any place with a rational method and fair standard. In 1969, the United Nations passed Declaration on Social Progress and Development, which mentioned that all people and the entire human kind should have the right to lead a life with dignity and freedom and to enjoy achievements of social progress.

Development of information technology, network technology and digital library has had a positive effect on a public library to guarantee cultural right of a citizen. It not only realizes diversification of document information carrier, branding and layering of document resources, and brings a visual impact and beauty enjoyment on people, but also makes retrieval more convenient, fast and cheaply-priced to use. Library consortia, library communitization, and construction of library service network promote construction of informationization among countries and regions, satisfy demand of globalization information and shorten distance between readers and the library. Especially, establishment of all sorts of data bases, information bases and knowledge bases enables human kind to employ the most advanced scientific and research results in a far distance.

\subsection{Readers' right to participate in social and cultural life}

The fifth Article in Manifesto of World Cultural Significance in 2001 stipulated, "Each one should have the right to participate in the cultural life he/she has chosen and to undertake his/her particular cultural activities.” The $47^{\text {th }}$ Article of the existing Constitution in China stipulates, "Citizens of the People's Republic of China have the freedom to participate in scientific research, literary and artistic creation and other cultural activities.” To guarantee citizens’ right to participate in cultural life can not only satisfy people’s increasingly growing spiritual and cultural demands, and realize their all-round development, but can also adequately activate their personal development potential and creative vigor.

At the time of finishing routine work, some public libraries also take the initiative to hold various cultural activities to satisfy people's demands upon spiritual and cultural life, such as, lectures about sinology, document discussion, course of lectures, exhibition of paintings and calligraphy, education of information literacy, chorus of the elderly and training of “young librarians", etc. For example, Place of Entertainment for Public Welfare of Mantingfang set up by the library in Xuhui District in Shanghai gives performance to the public free of charge each year, and has gained perfect social benefit. 


\subsection{Readers' right to share service of a library}

The target of public library to collect documents and inherit culture is to serve the society and to promote progress and prosperity of the social politics, economy and culture. From the perspective of institutional level, public library should become a tool to guarantee fair acquisition of information. Thus, each citizen has the right to share service in a public library.

The characteristics of libraries in the $21^{\text {st }}$ Century is as follows: free acquisition of information and knowledge; openness and share of information and knowledge resources; fair service; equal service to readers going to the library and not going to the library. Therefore, service offered by a public library is free, open, equal and cost-free. The free, open, equal and cost-free service means is not only ideal of the library career, but also embodiment of library spirit. Only if a library offers free, open, equal and cost-free service, can it satisfy citizens' spiritual and cultural demands, especially those in former revolutionary base areas, areas inhabited by minority nationalities, remote and border areas and poverty-stricken areas. The $17^{\text {th }}$ Session of the General Assembly put forward the slogan of "concentrating on coordinative development of urban, rural and district culture, and attempting to enrich spiritual and cultural life of labor workers in urban areas from rural and remote areas”, which is of great stimulus to establishment of the library public cultural service system that gradually spreads over the whole society, and especially construction of rural cultural service system.

\section{Conclusion}

Readers' right is the fundamental right of citizens, and is part of cultural right and educational right. Guarantee and realization of readers' right has significant meaning to acquisition of information, realization of cultural right, establishment of a great power in human resources, development of cultural production capability and development of socialism economy in an optimal and rapid speed.

\section{References}

Fan, Bingsi, et al. (2002). Discussion by Three People on Pursuit of the Library Spirit in the $20^{\text {th }}$ Century from a New Perspective in a New Century. Library, (3): 1-8.

Han, Jiandong. (2007). Calling for Humanistic Intension and Educational Functions of Modern Library. Library Journal, (9):3-5, 10.

IFLA/UNESCO. (2002). The Public Library Service: IFLA/UNESCO Guidelines, translated by Lin, Zuzao. Shanghai: Shanghai Scientific and Technological Literature Publishing House.

Kang, Xiaomin. (2008). Legal Characteristics of Readers' Rights. Journal of The Sichuan Society for Library Science, (6):75-77.

Li, Weihong. (2003). Discussion on Rights of Readers. Seeker, (6):140-142.

Liu, Zhongping. (2006). On Facing Populace's Library Concern. Library Development, (5):75-79.

Song, Ling. (2006). Exploration of Realizing Rural Readers' Reading Rights of Guangdong Mobile Library. Library Development, (1):27-29.

Ye, Ying. (2006). Scientized Library Science and Its Architecture of Issues. Journal of Library Science in China, (2): 15-18. 